\title{
DESIGN AND ANALYSIS OF AIR PREHEATER
}

\section{J EMEEMA $^{1}$, MD KHIMRAN UDDIN ${ }^{2} \&$ MD ASHFAN PASHA ${ }^{3}$}

${ }^{1}$ Associate Professor, Department of Mechanical Engineering, Vidya Jyothi Institute of Technology, Aziz Nagar, Hyderabad, Telangana, India

${ }^{2,3}$ Research Scholar, Department of Mechanical Engineering, Vidya Jyothi Institute of Technology, Aziz Nagar, Hyderabad, Telangana, India

\section{ABSTRACT}

Air preheater is one of the accessories of steam generators, that works as a heat exchanger that utilizes the heat of the flue gas of the boiler, heating the air needed for the combustion of the fuel, thereby increasing the thermal efficiency of the boiler. It makes a considerable contribution to improve the overall efficiency of fossil-fuel-fired power plants.

The paper presents the design of a Recuperative Tubular type, air-through-air Preheater with the staggered tube arrangement, designed to meet specific performance requirements, using the software application SOLIDWORKS. An analytical study was undertaken and various heat transfer performance parameters like outlet temperature of the air, inside and outside heat transfer coefficients, overall heat transfer coefficient and rate of heat transfer involving conduction and convection modes of heat transfer were found. The results were tabulated and graphically depicted. These results were validated using CFD analysis at 100\% load and were found to be in good agreement with each other, with very little deviation. These heat transfer parameters are critical in the designing and functioning of Air Preheater to get the desired output. Air flow phenomenon, flue gas flow phenomena, temperature distribution and pressure drop in the Air Preheater were discussed in the CFD analysis.

KEYWORDS: Air Preheater, Outlet Temperature of Air, Logarithmic Mean Temperature Difference LMTD, Nusselt Number, Prandtl Number, Reynolds Number, Overall Heat Transfer Coefficient \& Computational Fluid Dynamics(CFD)

Received: Apr 03, 2018; Accepted: May 25, 2018; Published: Jun 15, 2018; Paper Id.: IJMPERDJUN2018107

\section{INTRODUCTION}

Air Preheaters are designed to extract the hot exhaust energy which, when discharged unused into the atmosphere, could be wasted. Reduction of flue gas exit temperature helps in the reduction of harmful gases up to a certain extent. So, Air Preheaters contribute to controlling environmental pollution and global warming. Air Preheaters help in reducing coal consumption, which helps to counter the rising fuel prices and make a considerable contribution to improve the thermal efficiency of boilers and overall efficiency of fossil fuel fired power plants. Air Preheater is installed between the economic and chimney of the steam power plant as shown in Figure 1. 


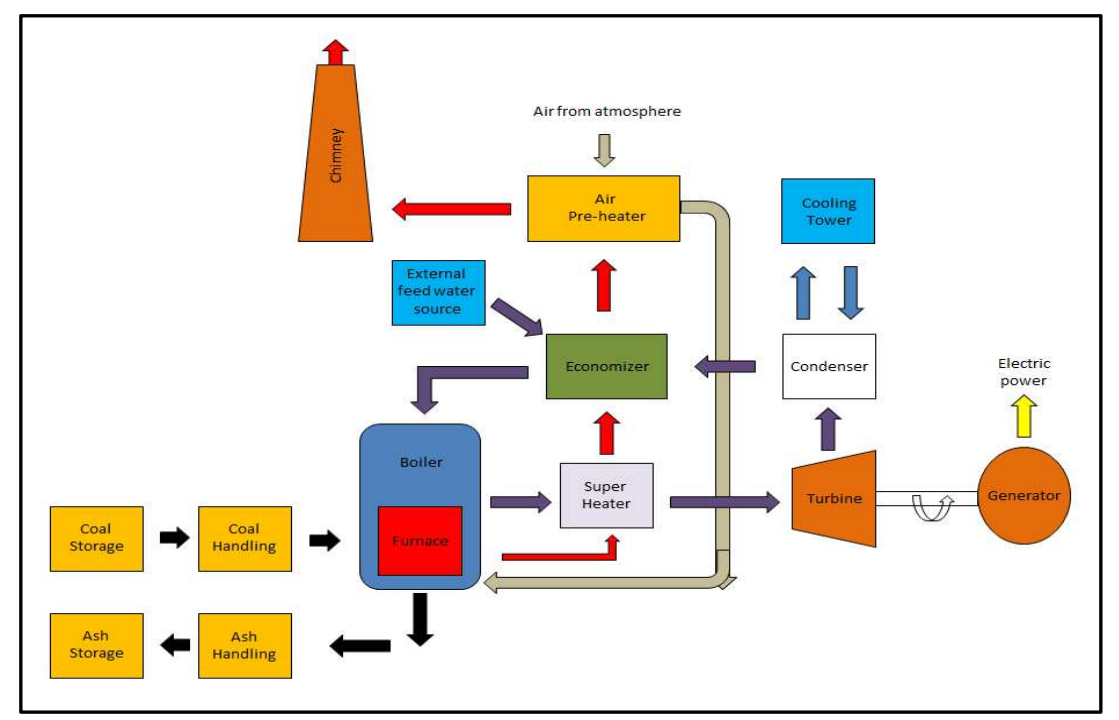

Figure 1: Schematic Diagram of Plant Layout

Recuperative Tubular type air preheaters have an enclosed rectangular box, type construction, consisting of several straight tubes connecting two thick end plates at two sides of the box. They consist of straight tube bundles which pass through the outlet ducting of the boiler and open at each end outside of the ducting. Inside the ducting, the hot furnace gases pass around the preheater tubes, transferring heat from the exhaust gas to the air inside the tubes. Ambient air is forced by a fan through the ducting at one end of the preheater tubes and at the other end, the heated air from inside of the tubes emerges into another set of ducting, which carries it to the boiler furnace for combustion.

In staggered arrangement, multiple rows of tubes are arranged in planes perpendicular to the airflow direction. Tubes in one plane are spaced at a pitch of "air side pitching" (also called transverse pitching). Next row of tubes are placed along the airflow direction, at half the "gas side pitching" (also called longitudinal pitching) but staggered to previous row of tubes by half of airside pitch. Third row is the repeat of $1^{\text {st }}$ row and fourth row is the repeat of $2^{\text {nd }}$ row and so on. This arrangement is repeated to get the total number of tubes per pass.

\section{DESIGN OF AIR PRE-HEATER}

The Air Preheater designed for the analysis is the Recuperative Tubular type with the staggered tube arrangement. It consists of 1488number of steel tubes/pipes arranged in 32 rows, with 47 tubes in $1^{\text {st }}$ row and 46 tubes in $2^{\text {nd }}$ row and so on. Either side of the tubes is welded into the plate. It is designed such that air flows through the tubes and flue gas flows over the tubes heating the tube surface. The design of Air Preheater is done in SOLIDWORKS which is a comprehensive suite of computational fluid dynamics software for modeling fluid flow and other related physical phenomena.

\section{Design Notations and Specifications of Air Preheater}

Inside diameter of tube $D_{i}=25 \mathrm{~mm}$

Outside diameter of tube $D_{0}=28 \mathrm{~mm}$

Length of tube $\mathrm{L}=1.66 \mathrm{~m}$

Width of tube $\mathrm{W}=2.35 \mathrm{~m}$ 
Number of tubes $n=1488$

The design and working process of air Preheater is shown in Figure 2.

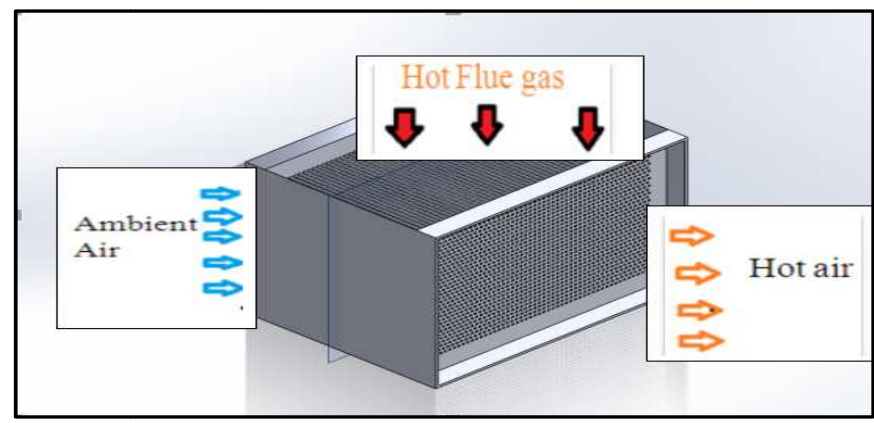

Figure 2: Design and Working Process of Air Pre-Heater

\section{HEAT TRANSFER TERMINOLOGY}

\section{Logarithmic Mean Temperature Difference LMTD}

The LMTD is a logarithmic average of the temperature difference between the hot fluid (flue gas) and cold fluid (air) at each end of the Air Pre-heater. The larger the LMTD, the more the heat transferred.

$$
\begin{aligned}
& \mathrm{LMTD}=\left(\Delta \mathrm{T}_{1}-\Delta \mathrm{T}_{2}\right) / \mathrm{LN} \times\left(\Delta \mathrm{T}_{1} / \Delta \mathrm{T}_{2}\right) \\
& \Delta \mathrm{T}_{1}=\mathrm{T}_{\mathrm{gi}}-\mathrm{T}_{\mathrm{ao}}=\text { Temperature difference between the two streams at end 1, } \\
& \Delta \mathrm{T}_{2}=\mathrm{T}_{\mathrm{go}}-\mathrm{T}_{\mathrm{ai}}=\text { Temperature difference between the two streams at end } 2 . \\
& \mathrm{T}_{\mathrm{gi}}=\text { Temperature of flue gas at inlet of air Preheater } \\
& \mathrm{T}_{\mathrm{go}}=\text { Temperature of flue gas at outlet of air Preheater } \\
& \mathrm{T}_{\mathrm{ai}}=\text { Temperature of air at inlet of air Preheater } \\
& \mathrm{T}_{\mathrm{ao}}=\text { Temperature of air at outlet of air Preheater } \\
& \text { For Cross-flow heat exchanger, (LMTD })_{\text {Crossflow }}(\mathrm{LMTD})_{\text {Counterflow }} \mathrm{x} \mathrm{F} \\
& \mathrm{F}=\text { Correction Factor obtained from a heat transfer data book }
\end{aligned}
$$

\section{Dimensionless Numbers in Forced Convection}

$$
\begin{aligned}
& \mathrm{Nu}=\text { Nusselt Number } \\
& \mathrm{Re}=\text { Reynolds Number } \\
& \mathrm{Pr}=\text { Prandtl Number }
\end{aligned}
$$

Overall Heat Transfer Coefficient Based on Outside Surface $\mathbf{U}_{\mathrm{o}}$ (with Fouling Factor)

$$
\begin{aligned}
& \frac{1}{\mathrm{U}_{0}}=\frac{1}{\mathrm{~h}_{0}}+\mathrm{R}_{\mathrm{fo}}+\frac{\mathrm{r}_{0}}{\mathrm{k}} \ln \frac{\mathrm{r}_{0}}{\mathrm{r}_{\mathrm{i}}}+\frac{\mathrm{r}_{0}}{\mathrm{r}_{\mathrm{i}}} \mathrm{R}_{\mathrm{fi}}+\frac{\mathrm{r}_{0}}{\mathrm{r}_{\mathrm{i}}} \times \frac{1}{\mathrm{~h}_{\mathrm{i}}} \\
& \mathrm{R}_{\mathrm{fo}_{\mathrm{o}}}=\text { Flue gas side or outside Fouling Factor }
\end{aligned}
$$


$\mathrm{R}_{\mathrm{fi}}=$ Air side or inside Fouling Factor

$\mathrm{h}_{\mathrm{o}}=$ Flue gas side or outside heat transfer coefficient

$\mathrm{h}_{\mathrm{i}}=$ Air side or inside heat transfer coefficient

$\mathrm{r}_{0}=$ Outside radius of the tube

$r_{i}=$ Inside radius of tube

$\mathrm{k}=$ Thermal conductivity of tube material

Overall Heat Transfer Coefficient Based on Outside Surface Area $\mathbf{U}_{\mathbf{0}}$ (without Fouling Factor)

$\frac{1}{\mathrm{U}_{0}}=\frac{1}{\mathrm{~h}_{0}}+\frac{\mathrm{r}_{0}}{\mathrm{k}} \ln \frac{\mathrm{r}_{0}}{\mathrm{r}_{\mathrm{i}}}+\frac{\mathrm{r}_{0}}{\mathrm{r}_{\mathrm{i}}} \times \frac{1}{\mathrm{~h}_{\mathrm{i}}}$

Note: Air Preheater is designed such that air flows inside the tubes and flue gas flow outside the tubes. Hence the flow parameters are denoted as 'inside' for air side and 'outside' for flue gas side.

Rate of Heat Transfer $\mathrm{Q}=\mathrm{U}_{\mathrm{o}} \mathrm{A}_{\mathrm{o}}(\mathrm{LMTD})_{\text {Crossflow }}$

$\mathrm{A}_{\mathrm{o}}=$ Outside surface area of the tube $=\pi \mathrm{D}_{0} \mathrm{Ln}$

\section{ANALYTICAL ANALYSIS OF AIR PRE-HEATER}

Input Parameters of Air Preheater At $100 \%$ Load

$\begin{array}{ll}\text { Inlet temperature of flue gas } & \mathrm{T}_{\mathrm{gi}}: 180^{\circ} \mathrm{C} \\ \text { Outlet temperature of flue gas } & \mathrm{T}_{\mathrm{go}}: 130^{\circ} \mathrm{C} \\ \text { Inlet temperature of air } \mathrm{T}_{\mathrm{ai}} & 30^{\circ} \mathrm{C} \\ \text { Volumetric flow rate of air } & 10.417 \mathrm{~m}^{3} / \mathrm{s} \\ \text { Volumetric flow rate of Flue Gas } & 13.88 \mathrm{~m}^{3} / \mathrm{s} \\ \text { Tube wall temperature Tw } & 120^{\circ} \mathrm{C}\end{array}$

The analysis is performed at three different loads $(40 \%, 100 \%$, and $120 \%)$ on the air preheater.

Note: The values of input Parameters vary for different loads.

\section{Output Parameters Found}

- The outlet temperature of Air, $\mathrm{T}_{\mathrm{ao}}$

- Inside Heat transfer coefficient (air side) $\mathrm{h}_{\mathrm{i}}$

- $\quad$ Outside heat transfer coefficient (flue gas side) $\mathrm{h}_{\mathrm{o}}$

- Overall heat transfer coefficient based on outside surface area $\mathrm{U}_{\mathrm{o}}$.

- $\quad$ Rate of heat transfer Q 


\section{Heat Transfer Analysis on Flue Gas Side}

Effective Area of passage of flue gases

$A=W \times L-\left(\right.$ No. of tubes in first row $\left.x D_{0} \times L\right)$

Velocity of Flue Gas V $=\frac{\text { Volumetric flow rate of flue gas }}{\text { Effective area of flue gas }}$

Bulk Temperature $\left(\mathrm{T}_{\mathrm{b}}\right)=\left(\mathrm{T}_{\mathrm{gi}}+\mathrm{T}_{\mathrm{go}}\right) / 2$

Film Temperature $\left(\mathrm{T}_{\mathrm{f}}\right)=\left(\mathrm{T}_{b}+\mathrm{T}_{\mathrm{w}}\right) / 2$

Properties of Flue gas taken at $\left(\mathrm{T}_{\mathrm{f}}\right)$ from the Heat Transfer Data Book

Density $(\rho)$

Kinematic Viscosity (v)

Prandtl Number (Pr)

Thermal Conductivity (k)

Specific heat $\left(\mathrm{C}_{\mathrm{pg}}\right)$

$\mathrm{R}_{\mathrm{e}}=\frac{\mathrm{VDo}}{\mathrm{v}}$

The value of the Reynolds number indicated that the flow on the flue gas side is Turbulent

Convective Heat Transfer Correlation between the dimensionless numbers obtained from Heat Transfer Data Book for Turbulent flow in forced convection is as follows.

Nusselt number $\mathrm{Nu}=0.33 \times \operatorname{Re}^{0.6} \times \operatorname{Pr}^{0.33}$

$$
\begin{aligned}
& \mathrm{Nu}=\frac{\mathrm{h}_{\mathrm{o}} \times \mathrm{D}_{0}}{\mathrm{k}} \\
& \mathrm{h}_{\mathrm{o}}=\frac{\mathrm{Nu} \times \mathrm{k}}{\mathrm{D}_{\mathrm{o}}} \\
& \mathrm{h}_{\mathrm{o}}=\text { Flue gas side heat transfer coefficient or outside heat transfer coefficient was obtained. }
\end{aligned}
$$

\section{Heat Transfer Analysis on Air Side}

An energy balance between hot and cold fluids gives:

$\mathrm{Q}=\mathrm{m}_{\mathrm{g}} \times \mathrm{C}_{\mathrm{pg}}\left(\mathrm{T}_{\mathrm{go}}-\mathrm{T}_{\mathrm{gi}}\right)=\mathrm{m}_{\mathrm{a}} \times \mathrm{C}_{\mathrm{pa}}\left(\mathrm{T}_{\mathrm{ao}}-\mathrm{T}_{\mathrm{ai}}\right)$

Where $\mathrm{m}_{\mathrm{g}}=$ mass flow rate of flue gas $=$ Volumetric flow rate of the flue gas $\mathrm{x}$ density of flue gas

$\mathrm{m}_{\mathrm{a}}=$ mass flow rate of air $=$ Volumetric flow rate of air $\mathrm{x}$ density of air

$\mathrm{T}_{\mathrm{ao}}=$ Temperature of air at outlet is obtained from the above equation

Bulk mean temperature of air $\mathrm{T}_{\mathrm{b}}=\frac{\mathrm{T}_{\mathrm{ao}}+\mathrm{T}_{\mathrm{ai}}}{2}$

Properties of air taken at $\left(\mathrm{T}_{\mathrm{b}}\right)$ from Heat Transfer Data Book 
Density $(\rho)$

Kinematic Viscosity (v)

Prandtl Number (Pr)

Thermal Conductivity (k)

Specific heat $\left(\mathrm{C}_{\mathrm{pa}}\right)$

$\mathrm{R}_{\mathrm{e}}=\frac{\mathrm{VDi}}{v}$

The value of the Reynolds number indicated that the flow on the air side is Turbulent

Convective Heat Transfer Correlation between the dimensionless numbers obtained from Heat Transfer Data Book for Turbulent flow in forced convection based on the value of the Reynolds number and L/D ratio is as follows.

Nusselt number $\mathrm{Nu}=0.023 \times \operatorname{Re}^{0.8} \times \operatorname{Pr}^{0.4}$

$$
\begin{aligned}
& \mathrm{Nu}=\frac{\mathrm{h}_{\mathrm{i}} \times \mathrm{D}_{\mathrm{i}}}{\mathrm{k}} \\
& \mathrm{h}_{\mathrm{i}}=\frac{\mathrm{Nu} \times \mathrm{k}}{\mathrm{D}_{\mathrm{i}}} \\
& \mathrm{h}_{\mathrm{i}}=\text { air side heat transfer coefficient or inside heat transfer coefficient was obtained. }
\end{aligned}
$$

Overall Heat Transfer Coefficient Based on Outside Surface Area $\mathbf{U}_{\text {o }}$ (with Fouling Factor)

$$
\begin{aligned}
& \frac{1}{\mathrm{U}_{0}}=\frac{1}{\mathrm{~h}_{0}}+\mathrm{R}_{\mathrm{fo}}+\frac{\mathrm{r}_{0}}{\mathrm{k}} \ln \frac{\mathrm{r}_{0}}{\mathrm{r}_{\mathrm{i}}}+\frac{\mathrm{r}_{0}}{\mathrm{r}_{\mathrm{i}}} \mathrm{R}_{\mathrm{fi}}+\frac{\mathrm{r}_{0}}{\mathrm{r}_{\mathrm{i}}} \times \frac{1}{\mathrm{~h}_{\mathrm{i}}} \\
& \mathrm{R}_{\mathrm{fo}}=0.002 \\
& \mathrm{R}_{\mathrm{fi}}=0.0001
\end{aligned}
$$

Overall Heat Transfer Coefficient Based on Outside Surface Area $\mathbf{U}_{\mathbf{0}}$ (without Fouling Factor)

$$
\frac{1}{\mathrm{U}_{0}}=\frac{1}{\mathrm{~h}_{0}}+\frac{\mathrm{r}_{0}}{\mathrm{k}} \ln \frac{\mathrm{r}_{0}}{\mathrm{r}_{\mathrm{i}}}+\frac{\mathrm{r}_{0}}{\mathrm{r}_{\mathrm{i}}} \times \frac{1}{\mathrm{~h}_{\mathrm{i}}}
$$

Rate of Heat Transfer $\mathbf{Q}=\mathrm{U}_{\mathrm{o}} \mathrm{A}_{\mathrm{o}}(\mathrm{LMTD})_{\text {Crossflow }}$

\section{CALCULATED VALUES IN TABULAR FORM}

Table 1: Flue Gas Side Values at Different Loads

\begin{tabular}{|c|c|c|c|c|c|c|}
\hline Load & Volumetric Flow Rate $\mathbf{~ m}^{\mathbf{3}} / \mathbf{s}$ & $\mathbf{T}_{\mathbf{g o}}$ & $\mathbf{R e}$ & $\mathbf{P r}$ & $\mathbf{N u}$ & $\begin{array}{c}\mathbf{h}_{\mathbf{0}} \\
\mathbf{W} / \mathbf{m}^{\mathbf{2}} \mathbf{K}\end{array}$ \\
\hline $40 \%$ & 5.55 & 150 & 3442.442 & 0.6815 & 38.519 & 48.19 \\
\hline $100 \%$ & 13.88 & 130 & 8795.3783 & 0.683 & 67.597 & 83.528 \\
\hline $120 \%$ & 16.656 & 135 & 10490.6 & 0.682 & 75.187 & 93.178 \\
\hline
\end{tabular}


Table 2: Air Side Values at Different Loads

\begin{tabular}{|c|c|c|c|c|c|c|}
\hline Load & $\begin{array}{c}\text { Volumetric Flow Rate } \\
\mathbf{m}^{\mathbf{3} / \mathbf{s}}\end{array}$ & $\mathbf{T}_{\mathbf{a o}} \square$ & $\mathbf{R e}$ & $\mathbf{P r}$ & $\mathbf{N u}$ & $\mathbf{h}_{\mathbf{i}} \mathbf{W} / \mathbf{m}^{\mathbf{2}} \mathbf{K}$ \\
\hline $40 \%$ & 5.55 & 47.94 & 8048.361 & 0.698 & 26.536 & 29.82 \\
\hline $100 \%$ & 13.88 & 89.31 & 18798.46 & 0.696 & 52.24 & 60.51 \\
\hline $120 \%$ & 16.656 & 83.67 & 22985.9 & 0.6966 & 61.38 & 70.52 \\
\hline
\end{tabular}

Table 3: Output Parameters at Different Loads

\begin{tabular}{|c|c|c|c|c|c|c|}
\hline Load & $\begin{array}{c}\text { Volumetric Flow Rate } \\
\mathbf{m}^{\mathbf{3}} / \mathbf{s}\end{array}$ & $\mathbf{T}_{\mathbf{a o}}$ & $\begin{array}{c}\mathbf{h}_{\mathbf{o}} \\
\mathbf{W} / \mathbf{m}^{\mathbf{2}} \mathbf{K}\end{array}$ & $\begin{array}{c}\mathbf{h}_{\mathbf{i}} \\
\mathbf{W} / \mathbf{m}^{\mathbf{2}} \mathbf{K}\end{array}$ & $\begin{array}{c}\mathbf{U}_{\mathbf{0}} \\
\mathbf{W} / \mathbf{m}^{\mathbf{2}} \mathbf{K}\end{array}$ & $\begin{array}{c}\mathbf{Q} \\
\mathbf{k W}\end{array}$ \\
\hline $40 \%$ & 5.55 & 47.94 & 48.19 & 29.82 & 17.12 & 420.12 \\
\hline $100 \%$ & 13.88 & 88.98 & 83.53 & 60.51 & 30.66 & 621.92 \\
\hline $120 \%$ & 16.656 & 83.67 & 93.17 & 70.52 & 34.78 & 760.89 \\
\hline
\end{tabular}

\section{CALCULATED VALUES IN GRAPHICAL FORM}

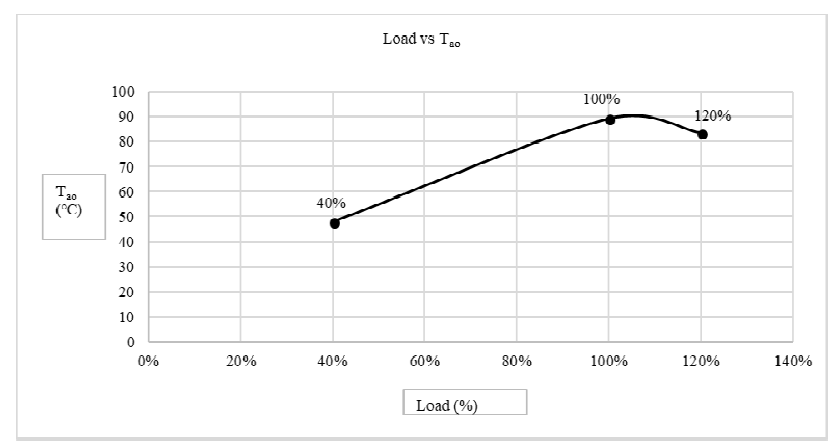

Graph 1: Load vs Outlet Temperature of Air $\left(\mathrm{T}_{\mathrm{ao}}\right)$

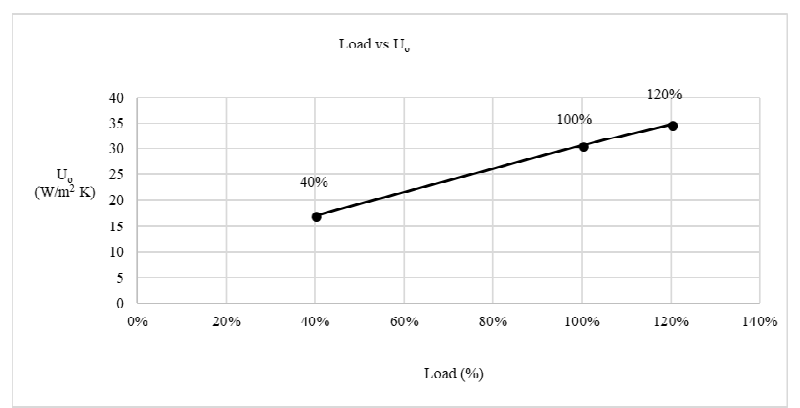

Graph 2: Load vs Overall Heat Transfer Coefficient $\left(\mathbf{U}_{0}\right)$

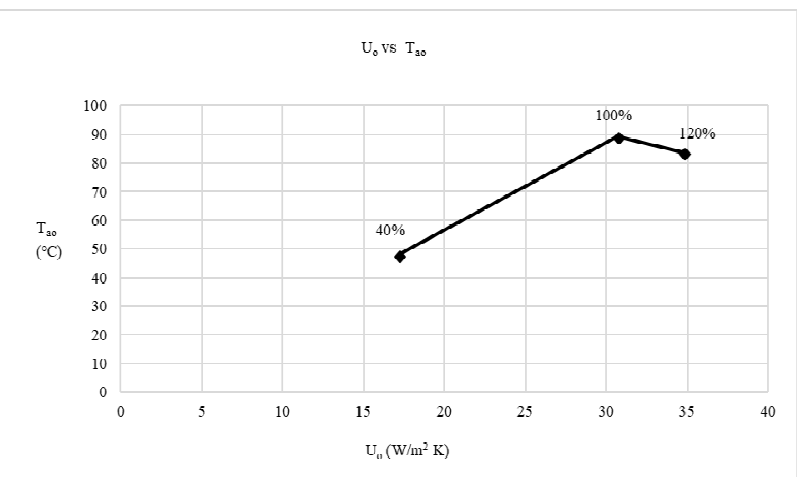

Graph 3: Overall Heat Transfer Coefficient $\left(U_{0}\right)$ vs

Outlet Temperature of Air $\left(T_{a o}\right)$ for Different Loads 


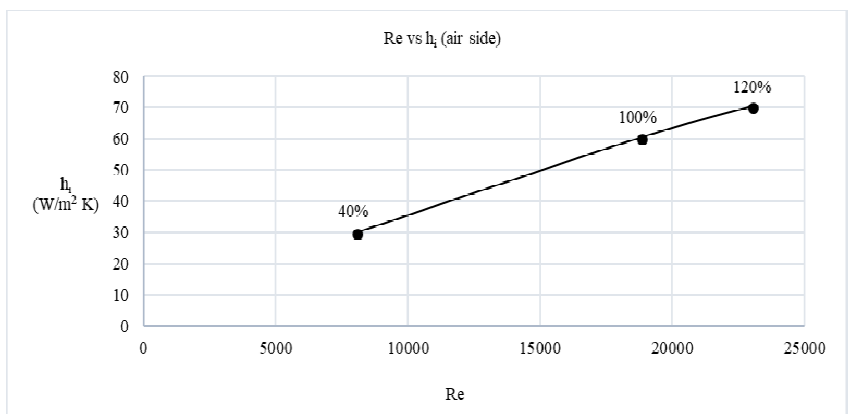

Graph 4: Reynolds Number (Re) vs Inside Heat Transfer Coefficient (hi) for Different Loads

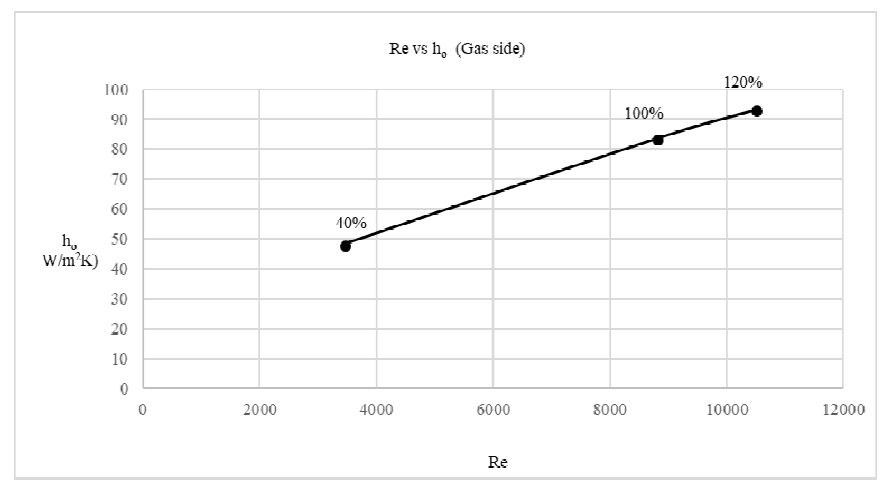

Graph 5: Reynolds Number (Re) vs Outside Heat Transfer Coefficient (ho) for Different Loads

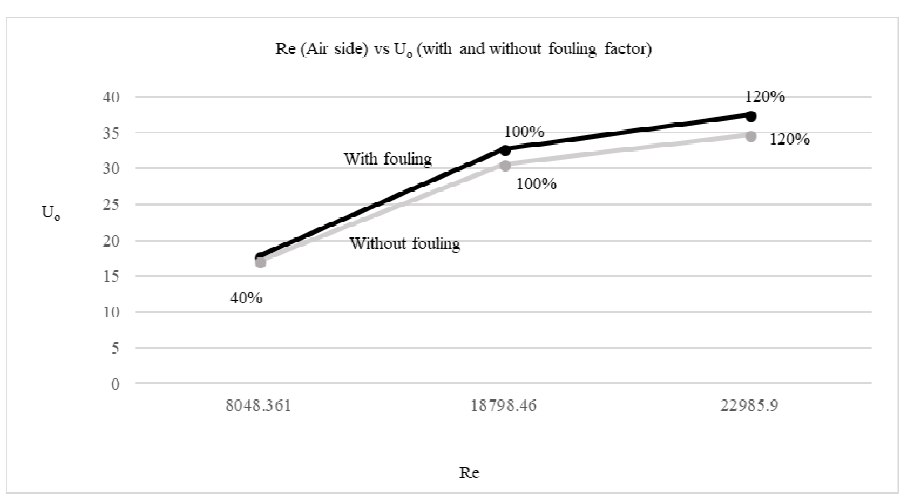

Graph 6: Reynolds Number (Re) on Air Side vs Overall Heat Transfer Coefficient (Uo) with and without Fouling Factor at Different Loads

\section{COMPUTATIONAL FLUID DYNAMICS (CFD)} ANALYSIS OF AIR PRE-HEATER

A CFD is a method for solving complex fluid flow and heat transfer problems on a computer. CFD allows the study of problems that are too difficult to solve using classical techniques. The flow inside the ESP is complex and this can be analyzed using the CFD tool, which provides an insight into the complex flow behavior.

The CFD Analysis is performed at $100 \%$ load to find the following parameters:

- $\quad$ Outlet temperature of air $\mathrm{T}_{\mathrm{ao}}$ 
- Outlet temperature of Flue Gas $\mathrm{T}_{\mathrm{go}}$

- Overall heat transfer coefficient $\mathrm{U}_{\mathrm{o}}$

- Temperature distribution along the length of the tube

- Pressure distribution along the length of the tube

Inlet Boundary Conditions for CFD Analysis is Shown in Figure 3

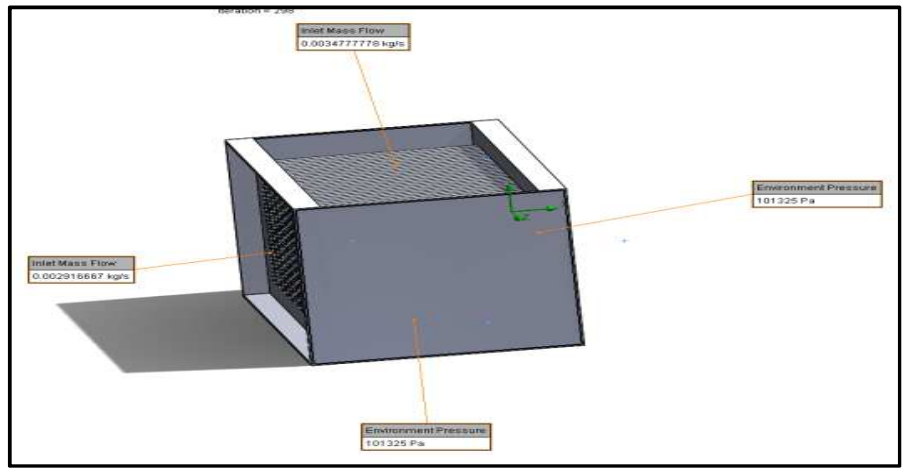

Figure 3: Inlet Boundary Conditions for CFD Analysis

Input parameters for CFD analysis (same values used in analytical analysis)

Inlet temperature of Air $\mathrm{T}_{\mathrm{ai}}=30^{\circ} \mathrm{C}$

Inlet temperature of flue gas $\mathrm{T}_{\mathrm{gi}}=180^{\circ} \mathrm{C}$

Volumetric flow rate of air $=\quad 10.417 \mathrm{~m}^{3} / \mathrm{s}$

Volumetric flow rate of Flue Gas $=13.88 \mathrm{~m}^{3} / \mathrm{s}$

\section{RESULTS FROM CFD ANALYSIS}

Temperature Variation of Air from Inlet to Outlet is shown in Figure 4

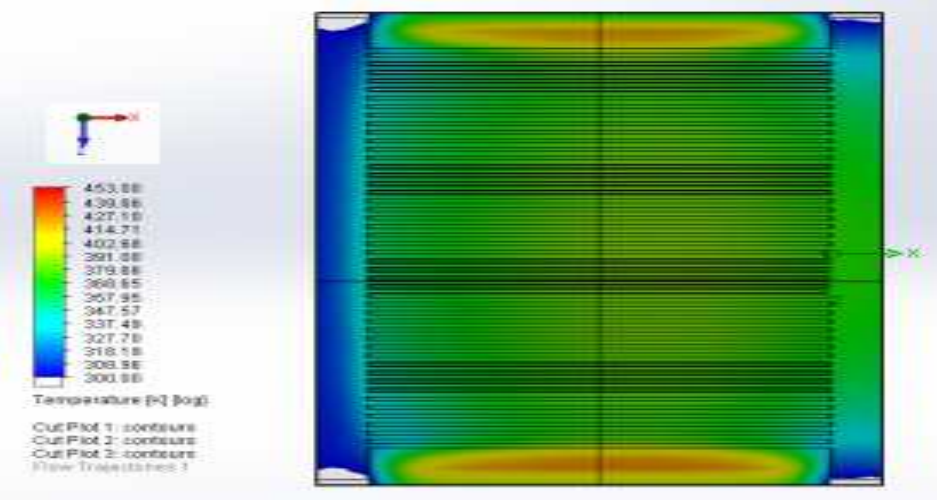

Figure 4: Top View of Air Pre-Heater with Inlet and Outlet flow Variation of Temperature of Air

Blue color indicates inlet temperature of ambient air

Green color indicates outlet temperature of hot air 
Temperature Variation of Flue Gas from Inlet to Outlet is shown in Figure 5
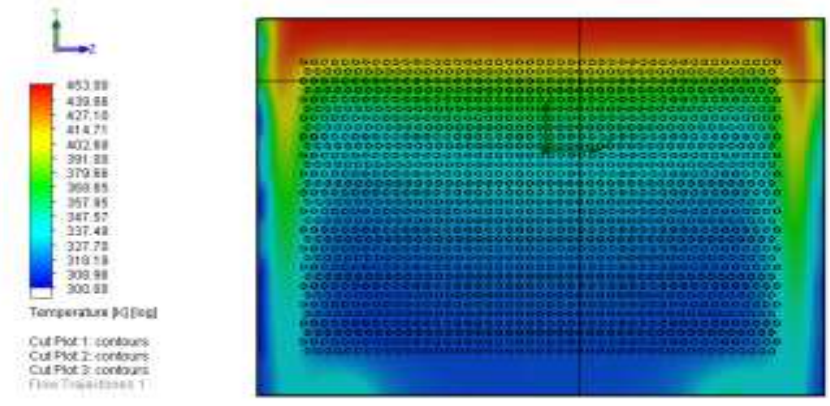

Figure 5: Front View of Air Pre-Heater with Inlet and Outlet flow Variation of Flue Gas Temperature

Velocity Variation of Flue Gas from Inlet to Outlet is shown in Figure 6
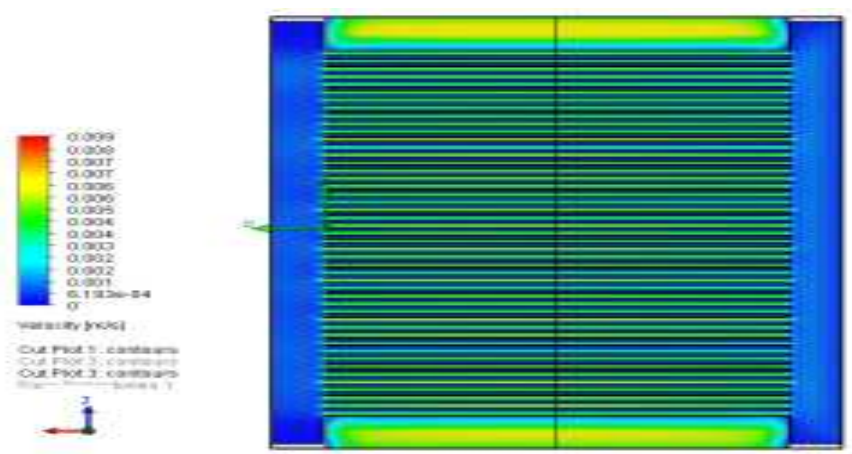

Figure 6: Top View of Air Pre-Heater with Inlet and Outlet Flow Variation of Velocity of Air

Pressure Variation of Air from Inlet to Outlet is shown in Figure 7
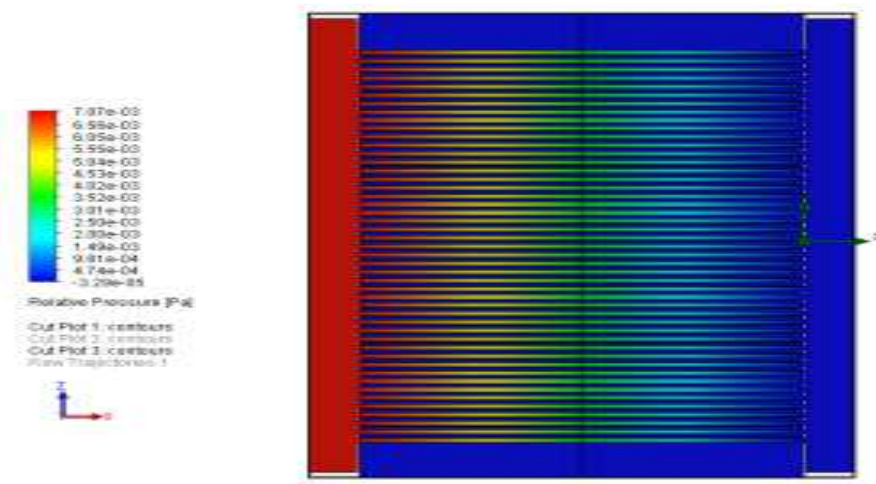

Figure 7: Top View of Air Pre-Heater with Inlet and Outlet Flow Variation of Relative Pressure of Air 


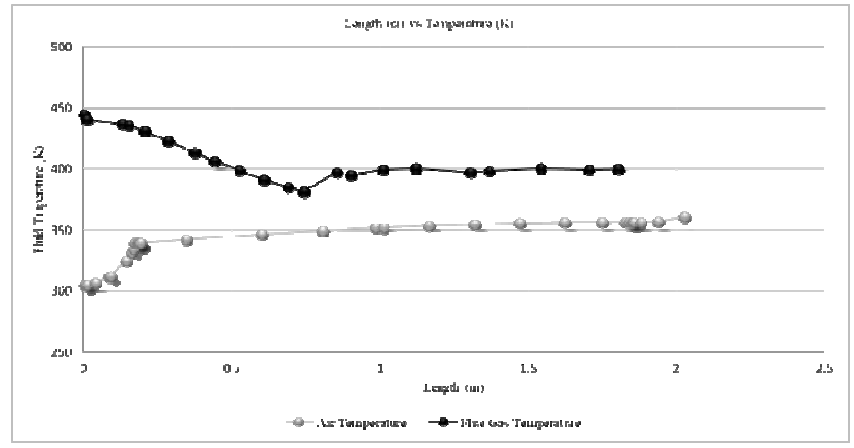

Graph 7: Temperature Distribution of Air and Flue Gas across the Length of Air Pre-Heater

Graph 8: Pressure Distribution across the Length of Air Pre-Heateris shown in Graph 8

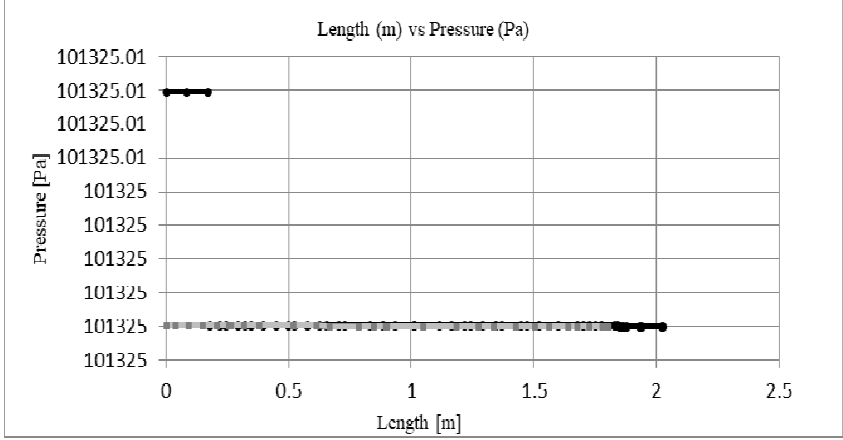

Graph 8: Pressure Distribution across the Length of Air Pre-Heater

\section{Graph 8 Legend}

Black line indicates the flue gas pressure

Gray line indicates the air pressure

\section{COMPARISON BETWEEN ANALYTICAL AND CFD ANALYSIS AT 100\% LOAD}

The output Heat Transfer parameters obtained from Analytical Analysis and CFD Analysis are Tabulated in Table4 for comparison.

Table 4: Values of Output Heat Transfer Parameters from Analytical \& CFD Analysis

\begin{tabular}{|l|c|c|}
\hline \multicolumn{1}{|c|}{ Parameter } & Analytical Analysis & Cfdanalysis \\
\hline Outlet temperature of air $\mathbf{T}_{\mathbf{a} \mathbf{0}}$ in $\square$ & 88.98 & 88.07 \\
\hline Outlet temperature of flue gas $\mathbf{T}_{\mathbf{g} \mathbf{0}}$ in $\square$ & 130 & 127.33 \\
\hline Overall heat transfer coefficient $\mathbf{U}_{\mathbf{o}}\left(\frac{\mathbf{W}}{\mathbf{m}^{\mathbf{2}} \mathbf{K}}\right)$ & 30.66 & 31.82 \\
\hline Rate of heat transfer Q in $\mathbf{~ k W}$ & 621.92 & 645.45 \\
\hline
\end{tabular}

To find the overall heat transfer coefficient $\mathrm{U}_{\mathrm{o}}$ in CFD analysis, the outlet Temperatures of Air and Flue gas obtained from CFD result are used to calculate the values of inside and outside heat transfer coefficients $h_{i}$ and $h_{0}$ and overall heat transfer coefficient $U_{0}$. 


\section{RESULTS AND DISCUSSIONS}

\section{Analytical Analysis}

The following observations can be made from graphs.

- Graph 3: $\mathrm{U}_{\mathrm{o}}$ increased with load. $\mathrm{T}_{\mathrm{ao}}$ is maximum at $100 \%$ load

- Graphs 4 \& 5: $\mathrm{h}_{\mathrm{i}}$ and $\mathrm{h}_{\mathrm{o}}$ increase with Reynolds number Re

- Graph 6: $\mathrm{U}_{\mathrm{o}}$ reduces due to Fouling by $6.5 \%$

- From Table 3, $\mathrm{h}_{\mathrm{i}}<\mathrm{h}_{\mathrm{o}}$ which indicates that the air side heat transfer coefficient offers more thermal resistance and controls the rate of heat transfer. Therefore, some enhancement technique like fins can be employed on the air side to compensate for low values of $h_{i}$.

\section{Comparison of Analytical \&CFD Analysis At 100\% Load}

- The outlet temperature of air $\mathrm{T}_{\mathrm{ao}}$ increased by $58.98^{\circ} \mathrm{C}$ in Analytical analysis and by $58.07^{\circ} \mathrm{C}$ in $\mathrm{CFD}$ analysis.

- The Overall heat transfer coefficient $\mathrm{U}_{\mathrm{o}}$ from $\mathrm{CFD}$ analysis has a deviation of $3.7 \%$ of Analytical analysis

- The outlet temperature of air $\mathrm{T}_{\mathrm{a}}$ from CFD analysis has a deviation of $1.03 \%$ of Analytical analysis

- Outlet temperature of flue gas $\mathrm{T}_{\mathrm{go}}$ from CFD analysis has a deviation of $2.05 \%$ of Analytical analysis

- The rate of heat transfer Q from CFD analysis has a deviation of $3.78 \%$ of Analytical analysis

\section{Temperature Distribution Graph in CFD Analysis}

From graph 7, it can be observed that:

- The temperature of ambient Air has increased by $57.98^{0} \mathrm{C}$, from $303.09 \mathrm{~K}\left(30.09{ }^{0} \mathrm{C}\right)$ to $361.07 \mathrm{~K}\left(88.07{ }^{0} \mathrm{C}\right)$

- $\quad$ The temperature of flue gas has decreased by $52.73^{0} \mathrm{C}$, from $453.06 \mathrm{~K}\left(180.06{ }^{0} \mathrm{C}\right)$ to $400.33 \mathrm{~K}\left(127.33{ }^{0} \mathrm{C}\right)$

\section{Pressure Distribution Graph in CFD Analysis}

Graph 8 indicates that the pressure of flue gas along the length of Air Preheater has dropped by $0.01 \mathrm{~Pa}$, from 101325.01 $\mathrm{Pa}$ to $101325 \mathrm{~Pa}$. Hence, it can be concluded that the pressure drop along the Air Preheater is very less.

\section{CONCLUSIONS}

From the design and analysis of Air Preheater, it can be concluded that the heat transfer performance parameters like outlet temperature of air $\mathrm{T}_{\mathrm{a} o}$, outlet temperature of flue gas $\mathrm{T}_{\mathrm{go}}$, overall heat transfer coefficient based on outside surface area $\mathrm{U}_{\mathrm{o}}$ and rate of heat transfer $\mathrm{Q}$ obtained from analytical analysis are in good agreement with the corresponding values obtained from CFD analysis, with very little deviation. Hence it can be concluded that these design parameters of air Preheater met with the performance requirements as intended. It can also be concluded that the designed air Preheaterserves the purpose of extracting heat from the flue gas of boilers, which can be used to preheat the air required for the combustion of the fuel in the boilers, thereby increasing thermal efficiency of the boiler, ultimately making a considerable contribution to improve the overall efficiency of fossil-fuel-fired power plants. 


\section{REFERENCES}

For Journal Papers:

1. Das* et al., 5(6). (June 2016). Thermodynamic Analysis of Recuperative Air Preheater. ISSN: 2277-9655.

2. P. N. Sapkal et al., (2011). Optimization of Air Preheater Design for the Enhancement of Heat Transfer Coefficient, International Journal of Applied Research in Mechanical Engineering (IJARME), ISSN: 2231 -5950, Volume-1, Issue-2.

3. Stephen K. Storm et al., (2011). Advancements with Regenerative Airheater Design, Performance and Reliability, POWERGEN Europe.

4. A Hussein, N., \& Jawdat Kadhim, A. (2017). Spectroscopic and Electrical Properties of Phthalocyaninato Cobalt (II).

5. Patel, B. N., \& Subhedar, D. (2016). Experimental and Numerical Investigation of Diesel Engine Turbocharger

6. P. N. Sapkal, et al., To optimize air preheater design for better performance. NEW ASPECTS of FLUID MECHANICS, HEAT TRANSFER and ENVIRONMENT. ISSN: 1792-4596, ISBN: 978-960-474-215-8, PP.61-69.

7. Juangjandee, P. and Sucharitakul, T. (2004). Performance Evaluation of Cross-Flow Heat Exchanger in Coal-Fired Power Plant under Particulate Condition, 18th Conference of Mechanical Engineering Network of Thailand, Khon Kaen University, Thailand.

8. HUSSIEN, Z. Y., \& RESAN, K. K. (2017). Effects of Ultraviolet Radiation With and Without Heat, on the Fatigue Behavior Of Below-Knee Prosthetic Sockets. International Journal of Mechanical and Production Engineering Research and Development (IJMPERD), 7(6).

9. Rakesh Kumar \& Sanjeev Jain, Performance Evaluation of air pre-heater at off design condition, Dept of Mech Engg, IIT, New Delhi.

10. Rasheed, W. A., Ahmed, S. S., \& Ghyadh, N. A. (2016). Investigation Potential Flow About Curved Wing Using Panel Method. For Books:

1. Incropera, F. P. and Dewitt, D. P., (2002). Introduction to Heat Transfer, 4thedition, John Wiley \& Sons Inc., USA.

2. Shah, R. K., Sekulic, D. P., (2003). Fundamentals of Heat Exchanger Design, John Wiley \& Sons Inc., Canada.

3. Donald Q. Kern (2004). Process Heat Transfer, Tata McGraw-Hill Publication, pp. 701.

4. P. K. Nag. Heat and Mass Transfer, Third Edition, McGraw Hill Education (India) Private Limited. 
